\title{
ANALISIS KEPUASAN KONSUMEN TERHADAP PRODUK KERIPIK SALAK UMKM SALAK CRISTAL DI KECAMATAN TURI KABUPATEN SLEMAN YOGYAKARTA
}

\author{
Virekha Yolanda1), Suyono ${ }^{2)}$, dan Irene Kartika Eka Wijayanti3) \\ 1)Program Studi Agribisnis, Fakultas Pertanian Universitas Jenderal Soedirman \\ 2,3)Departemen Sosial Ekonomi, Fakultas Pertanian Universitas Jenderal Soedirman \\ Jl. DR. Soeparno No. 63, Grendeng, Kec. Purwokerto Utara, Jawa Tengah, Indonesia \\ 1)e-mail: virekha.yolanda@gmail.com
}

(Diterima 8 Mei 2020 / Disetujui 29 Juni 2020)

\begin{abstract}
UMKM Salak Cristal is an agro-industry that is engaged in processing salak into various processed salak products. UMKM Salak Cristal has offline and online sales, but less consumer noticed and marketing strategies. UMKM Salak Cristal is not the only salak manufacture producer in Sleman. Therefore it makes UMKM Salak Cristal need information on customer satisfaction to develop appropriate marketing strategies to know changes in consumer needs and achieve customer satisfaction. Accordingly, researchers need to analyze customer satisfaction to help UMKM Salak Cristal in developing the right marketing strategy. This study aimed to 1) Analyze the level of satisfaction with salak chips at UMKM Salak Cristal Turi District, Sleman Regency, Yogyakarta; 2) Determine the marketing strategies that can be done in UMKM Salak Cristal Turi District, Sleman Regency, Yogyakarta. The method of this research used survey method and the sampling method used in this study was the Non-probability sampling method with the accidental sampling technique. A total of 100 respondents were calculated using a linear time function formula. The methods of this research are used Important Performance Analysis (IPA) and Customer Satisfaction Index (CSI). The results showed that: 1) Customer satisfaction to salak chips product in UMKM Salak Cristal is on the criterion of satisfaction, 2) Product attributes that must be prioritized to be improved are taste variations, sales and online promotions, store locations, employee uniforms, neat-looking employees, payment processing, displays adjust of products, and product price tags.
\end{abstract}

Keywords: customer satisfaction, marketing strategy, product attributes, performance, salak chips

\begin{abstract}
ABSTRAK
UMKM Salak Cristal merupakan agroindustri yang bergerak pada pengolahan salak menjadi aneka produk olahan salak. UMKM Salak Cristal telah melakukan penjualan secara offline dan online, akan tetapi kurang memperhatikan konsumen serta strategi pemasaran. UMKM Salak Cristal bukanlah satusatunya produsen pengolah salak di Sleman. Hal tersebut, membuat UMKM Salak Cristal membutuhkan informasi kepuasan konsumen untuk menyusun strategi pemasaran yang tepat agar mengetahui perubahan kebutuhan konsumen dan mencapai kepuasan konsumen. Oleh karena itu, peneliti perlu menganalisis kepuasan konsumen untuk membantu UMKM Salak Cristal dalam menyusun strategi pemasaran yang tepat. Penelitian ini bertujuan untuk: 1) Menganalisis tingkat kepuasan terhadap produk keripik salak pada UMKM Salak Cristal Kecamatan Turi, Kabupaten Sleman, Yogyakarta; 2) Menganalisis strategi pemasaran yang dapat dilakukan untuk meningkatkan kepuasan konsumen terhadap produk keripik salak UMKM Salak Cristal Kecamatan Turi, Kabupaten Sleman, Yogyakarta. Metode penelitian yang digunakan adalah survei, dan metode pengambilan sampel yang digunakan pada penelitian ini adalah metode Non-probability sampling dengan teknik accidental sampling. Besarnya sampel sebanyak 100 responden dihitung menggunakan rumus linear time function. Metode analisis data yang digunakan adalah Customer Satisfaction Index (CSI) dan Importance Performance Analysis (IPA). Hasil penelitian menunjukan bahwa: 1) Nilai tingkat kepuasan konsumen terhadap atribut produk keripik salak UMKM Salak Cristal yaitu berada pada kriteria puas, 2) Strategi yang dapat diterapkan yaitu memperbaiki beberapa atribut yang harus ditingkatkan yaitu variasi rasa, penjualan online, promosi online, lokasi toko, seragam karyawan, kerapihan karyawan, proses pembayaran, display sesuai jumlah produk, dan label harga produk.
\end{abstract}

Kata kunci: atribut produk, keripik salak, kinerja, kepuasan konsumen, strategi pemasaran 


\section{PENDAHULUAN}

Sektor pertanian merupakan penghasil sumber daya hayati, di mana sumber daya hayati tersebut dapat menyokong sektor-sektor lainnya. Menurut Badan Pusat Statistik (2019), kontribusi sektor pertanian terhadap Produk Domestik Bruto (PDB) menempati urutan ketiga setelah sektor industri pengolahan dan sektor perdagangan selama empat tahun terakhir. Sektor pertanian Indonesia memiliki beragam jenis tanaman, hal ini didukung dengan kondisi iklim masing-masing daerah yang berbeda. Masingmasing daerah memiliki komoditas unggulan di sektor pertanian.

Salak merupakan komoditas unggulan di sektor pertanian Provinsi DIY karena paling banyak diproduksi. Menurut BPS Hortikultura DIY (2019), terdapat empat komoditi buah-buahan yang mempunyai tingkat produksi tertinggi di Provinsi DIY pada 2014-2018 yaitu buah salak, mangga, pisang, dan nangka. Komoditas salak memiliki persentase rata-rata produksi tahunan yang lebih besar dibanding dengan buah lainnya yaitu sebesar 39,8 persen.

Produksi salak tahun 2018 sebesar 902.955 kwintal yang sebagian besar dihasilkan di Kabupaten Sleman yaitu mencapai 882.964 kwintal $(97,2 \%)$ dan sisanya dihasilkan oleh Kabupaten Kulon Progo (BPS DIY, 2018). Hal tersebut menunjukkan bahwa, Kabupaten Sleman merupakan kabupaten sentra salak di Provinsi DIY. Komoditas salak yang banyak dikembangkan di Kabupaten Sleman yaitu salak pondoh dan salak gading. Produksi tanaman salak pondoh mengalami peningkatan dari tahun 2017 sebanyak 692.815 kwintal menjadi 730.053 kwintal pada tahun 2018, sedangkan produksi tanaman salak gading konstan pada tahun 2017 dan 2018 yaitu sebanyak 581 kwintal (BPS Sleman, 2019).

Ketika panen raya, buah salak melimpah dan harga yang diterima petani salak sangat rendah. Harga yang diterima petani saat panen raya kurang dari Rp3.000,00 (Bimantio, 2018). Salak yang mudah rusak dan memiliki umur simpan yang relatif pendek menjadi risiko pada usahatani salak. Salah satu upaya mempertahankan mutu dan daya simpan buah adalah mengolahnya menjadi makanan kering (keripik).
Keripik mempunyai masa simpan atau konsumsi yang relatif lebih lama dibandingkan produk olahan lainnya. Keripik olahan salak ini merupakan potensi dan peluang bisnis yang besar, terlebih Kabupaten Sleman merupakan sentra salak di DIY.

Salah satu UMKM yang melakukan pengolahan buah salak menjadi keripik yaitu UMKM Salak Cristal di Kecamatan Turi, Kabupaten Sleman. UMKM Salak Cristal merupakan pionir usaha pengolahan salak di Sleman yang telah berdiri sejak 2008 dengan memanfaatkan hasil produksi petani salak Sleman lokal sehingga mendukung keberlangsungan petani salak Sleman. Lokasi toko yang berdekatan dengan beberapa desa wisata menjadikan wisatawan sebagai target pasarnya. UMKM Salak Cristal telah melakukan penjualan secara offline dan online, akan tetapi kurang memperhatikan konsumen serta strategi pemasaran.

UMKM Salak Cristal perlu memperhatikan konsumen untuk meningkatkan kepuasan konsumen, karena kepuasan konsumen dapat mempengaruhi omset penjualan yang dihasilkan. Jika konsumen merasa puas akan suatu produk maka permintaan meningkat dan omset penjualan pun ikut naik, sebaliknya jika konsumen tidak merasa puas maka permintaan akan menurun begitu juga dengan omset penjualan. Namun, menurut survei pendahuluan, omset yang didapatkan UMKM Salak Cristal mengalami penurunan selama dua tahun terakhir.

Terlebih UMKM Salak Cristal bukanlah satu-satunya produsen pengolah salak di Sleman. Terdapat beberapa agroindustri pengolahan salak di Kabupaten Seman, dapat dilihat pada Tabel 1. Hal tersebut, membuat UMKM Salak Cristal membutuhkan informasi kepuasan konsumen untuk menyusun strategi pemasaran yang tepat agar mengetahui perubahan kebutuhan konsumen dan mencapai kepuasan konsumen. Konsumen yang puas akan dapat menceritakan kepada konsumen lain tentang kelebihan produk yang mereka dapatkan, sehingga dapat menimbulkan citra baik dikalangan para konsumen. Oleh karena itu, peneliti perlu menganalisis kepuasan konsumen untuk membantu UMKM Salak Cristal dalam menyusun strategi pemasaran yang tepat. 
Tabel 1. Jumlah Unit Usaha Pengolahan Salak di Kabupaten Sleman

\begin{tabular}{lcc}
\hline \multicolumn{1}{c}{ Jenis Usaha } & $\begin{array}{c}\text { Jumlah Usaha } \\
\text { (Unit) }\end{array}$ & $\begin{array}{c}\text { Persentase } \\
\text { (\%) }\end{array}$ \\
\hline Aneka olahan salak & 7 & 24 \\
Keripik salak & 5 & 17 \\
Dodol salak & 7 & 24 \\
Wajik salak & 2 & 7 \\
Sari salak & 1 & 3 \\
Onde-onde salak & 1 & 3 \\
Stik salak & 1 & 3 \\
Suwar-suwir salak & 1 & 3 \\
Geplak salak & 1 & 3 \\
Sirup salak & 1 & 3 \\
Jenang salak & 1 & 3 \\
Pia \& Cocktail & 1 & 3 \\
\hline Jumlah & $\mathbf{2 9}$ & $\mathbf{1 0 0}$ \\
\hline Sumber: Dinas Perindustrian Perdagang dan Kop
\end{tabular}

Sumber: Dinas Perindustrian, Perdagangan, dan Koperasi Kabupaten Sleman, 2019

Berdasarkan uraian di atas tujuan penelitian ini adalah: 1) Menganalisis tingkat kepuasan terhadap produk keripik salak pada UMKM Salak Cristal Kecamatan Turi, Kabupaten Sleman, Yogyakarta; 2) Menganalisis strategi pemasaran yang dapat dilakukan untuk meningkatkan kepuasan konsumen terhadap produk keripik salak UMKM Salak Cristal Kecamatan Turi, Kabupaten Sleman, Yogyakarta.

\section{METODE}

\section{TEMPAT DAN WAKTU}

Penelitian ini dilakukan di UMKM Salak Cristal Kecamatan Turi, Kabupaten Sleman, Yogyakarta. Pemilihan tempat dilakukan secara sengaja (purposive). Hal ini didasarkan atas pertimbangan bahwa tempat tersebut merupakan pionir usaha aneka olahan salak di Kabupaten Sleman. Penelitian ini dilaksanakan pada bulan Februari 2020.

\section{PENGUMPULAN DATA}

Data yang dikumpulkan dalam penelitian ini adalah data primer dan data sekunder. Data primer diperoleh dari wawancara yang berpedoman pada kuesioner yang telah disiapkan. Data sekunder diperoleh dari instansi terkait dalam penelitian ini.

Metode pengambilan sampel yang digunakan pada penelitian ini adalah metode Nonprobability sampling yaitu tidak memberi peluang atau kesempatan yang sama bagi setiap unsur atau anggota populasi untuk dipilih menjadi sampel, dan menggunakan teknik accidental sampling karena penentuan sampel secara kebetulan atau insidental ketika peneliti bertemu dengan konsumen yang dapat digunakan sebagai sampel (Sugiyono, 2014). Responden yang dipilih pada penelitian ini merupakan konsumen yang telah melakukan pembelian dan telah mengkonsumsi produk keripik salak UMKM Salak Cristal.

Besarnya sampel dihitung menggunakan linear time function. Menurut Umar (2002), pengambilan sampel berdasarkan linear time function dapat dilakukan bila jumlah populasinya tidak dapat diketahui secara pasti. Pengambilan sampel dilakukan selama 30 hari karena waktu tersebut dinilai telah dapat mewakili untuk mendapatkan informasi yang dibutuhkan (Fauzi, 2018). Besarnya sampel yang dihitung berdasarkan linear time function dengan menggunakan rumus sebagai berikut:

$$
n=\frac{T-t_{o}}{t_{1}}=\frac{720-180}{6}=90 \text { responden }
$$

Keterangan:

$\mathrm{n}=$ Jumlah sampel

$\mathrm{T}=$ Waktu yang tersedia untuk penelitian (30 hari $\times 24$ jam/hari = 720 jam)

$t_{0}=$ Waktu tetap yang tidak tergantung pada besarnya sampel, yaitu waktu pengambilan sampel (6 jam/hari x 30 hari $=180$ jam)

$\mathrm{t}_{1}=$ Waktu yang digunakan setiap sampel unit, yaitu waktu yang digunakan responden untuk mengisi kuesioner $(0,2$ jam/hari x 30 hari $=6$ jam)

Menurut penelitian Fauzi (2018), waktu yang digunakan responden untuk mengisi kuesioner yaitu 0,5 jam. Namun, saat melakukan uji coba pengisian kuesioner penelitian pada beberapa orang rata-rata hanya memerlukan waktu rata-rata $0,2 \mathrm{jam}$. Berdasarkan perhitungan tersebut, jumlah sampel sebanyak 90 responden. Syarat minimum sebesar 90 responden, maka penelitian ini mengambil 100 responden sebagai sampel.

\section{METODE ANALISIS DATA Uji Validitas dan Reliabilitas}

Sebelum dilakukan analisis data, terlebih dahulu dilakukan uji validitas dan reliabilitas 
untuk mengetahui apakah kuesioner tersebut valid dan reliabel. Uji validitas dan reliabilitas dilakukan pada kuesioner tingkat kepentingan dan tingkat kepuasan terhadap 30 responden. Uji validitas dilakukan dengan melihat pearson correlation atau nilai rhitung, sedangkan uji reliabilitas dapat diukur dengan menggunakan cronbach's alpha. Uji validitas dan reliabilitas dilakukan menggunakan program SPSS (Statistical Product and Service Solution). Semakin tinggi nilai validasi menunjukkan bahwa kuesioner semakin tepat mengenai sasaran yang diinginkan dan konsisten dengan tujuan penyebaran kuesioner. Semakin tinggi nilai reliabilitas maka akan memberikan hasil pengukuran yang konsisten dan dapat dipercaya.

Hasil uji validitas menyatakan bahwa seluruh 35 pernyataan yang terdapat pada kuesioner tingkat kepentingan dan tingkat kepuasan dinyatakan valid karena memiliki nilai pearson correlation atau $\mathrm{r}_{\text {hitung }}$ lebih besar dari rtabel, sehingga tidak ada atribut yang dikeluarkan. Hasil uji reliabilitas pada kuisioner tingkat kepentingan dan tingkat kepuasan diketahui bahwa nilai Cronbach Alpha pada kuesioner tingkat kepentingan sebesar 0,977 dan tingkat kepuasan sebesar 0,935. Cronbach Alpha tersebut berada diantara $>0,80-1,00$, sehingga dapat disimpulkan bahwa seluruh instrumen penelitian dapat dinyatakan reliabel atau handal.

\section{Analisis Deskriptif}

Metode ini bertujuan untuk menguraikan tentang sifat-sifat atau karakteristik dari suatu keadaan dan membuat deskripsi atau gambaran yang sistematis dan akurat mengenai fakta-fakta dan sifat-sifat dari fenomena yang diselidiki (Arikunto, 2006). Analisis deskriptif bekerja dengan mendeskripsikan gambaran umum tempat penelitian dan menguraikan data hasil analisis.

\section{Analisis Kepuasan Konsumen}

1. Customer Satisfaction Index (CSI)

CSI digunakan untuk mengukur tingkat kepuasan konsumen terhadap atribut produk yang dapat digunakan sebagai acuan untuk menentukan strategi usaha dimasa yang akan datang. Cara menghitung indeks kepuasan konsumen (Aritonang, 2005), yaitu:

a. Menentukan Mean Importance Score (MIS), dengan rumus:

$$
M I S=\frac{\sum_{i=1}^{n} Y i}{n}
$$

b. Menghitung Weighted Factor (WF), dengan rumus:

$$
W F i=\frac{M I S i}{\sum_{i=1}^{p} M I S i} \times 100 \%
$$

c. Menentukan Mean Satisfaction Score (MSS), dengan rumus:

$$
M S S=\frac{\sum_{i=1}^{n} \quad X i}{n}
$$

d. Menghitung Weighting Score (WS), rumus:

$$
W S i=W F i x M S S i
$$

e. Menentukan Customer Satisfaction Index (CSI), dengan rumus:

$$
C S I=\frac{\sum_{i=1}^{p} \quad W S i}{H S} \times 100 \%
$$

2. Importance Performance Analysis (IPA) Model Importance Performance Analysis (IPA) diperkenalkan pertama kali oleh Martilla dan James (1977). Model ini bertujuan untuk mengukur hubungan antara persepsi konsumen dan prioritas peningkatan kualitas produk/jasa yang dikenal pula sebagai quadrant analysis. Berdasarkan hasi penilaian tingkat kepentingan dan hasil penilaian kinerja, maka akan dihasilkan suatu perhitungan mengenai tingkat kesesuaian antara kepentingan dan tingkat pelaksanaanya. Tingkat kesesuaian tersebut yang akan menentukan urutan prioritas peningkatan faktor yang mempengaruhi kepuasan konsumen. Tingkat kesesuaian tersebut dapat dihitung dengan rumus persamaan sebagai berikut:

$$
T k=\frac{X i}{Y i} \times 100 \%
$$


Keterangan :

Tk = Tingkat kesesuaian responden

$\mathrm{Xi}=$ Skor penilaian kinerja

Yi = Skor penilaian kepentingan

Kinerja dianggap telah memenuhi kepuasan konsumen jika Tk > 100\% dan sebaliknya, jika besar $\mathrm{Tk}<100 \%$ maka kinerja dianggap belum memenuhi kepuasan konsumen. Setelah diketahui tingkat kepentingan dan kinerja atribut, selanjutnya yaitu memetakan hasil perhitungan ke dalam diagram Kartesius. Masing-masing atribut diposisikan dalam sebuah diagram, dimana skor rata-rata penilaian terhadap tingkat kinerja (X) menunjukkan posisi suatu atribut pada sumbu $\mathrm{X}$, sementara posisi atribut pada sumbu Y, ditunjukkan oleh skor rata-rata tingkat kepentingan terhadap atribut (Y). Rumus yang digunakan sebagai berikut:

$$
\underline{X}=\frac{\sum \quad X i}{n} \quad \underline{Y}=\frac{\sum \quad Y i}{n}
$$

Keterangan:

$\underline{X}=$ Skor rata-rata tingkat kinerja

$\underline{Y}=$ Skor rata-rata kepentingan

$\overline{\mathrm{n}}=$ Jumlah responden

Diagram kartesius adalah diagram yang terdiri dari empat bagian yang dibatasi oleh dua buah bagian garis yang terpotong tegak lurus pada titik X dan Y. Garis X adalah rata-rata dari bobot tingkat kinerja atribut, sedangkan $Y$ merupakan rata-rata dari tingkat kepentingan seluruh faktor yang mempengaruhi kepuasan konsumen, rumus yang digunakan yaitu:

$$
\bar{X}_{1}=\frac{\sum_{i=1}^{n} \quad \underline{X_{1}}}{K} \quad Y_{1}^{=}=\frac{\sum_{i=1}^{n} \quad \underline{Y_{1}}}{K}
$$

\section{Keterangan:}

$\bar{X}_{1}=$ Rata- rata dari rata-rata skor kinerja

$Y_{1}^{\bar{E}}=$ Rata-rata dari rata-rata skor kepentingan

$K$ = Banyaknya atribut yang mempengaruhi penilaian kinerja

Nilai atribut $\mathrm{X}$ dan $\mathrm{Y}$ digunakan sebagai pasangan koordinat titik-titik memposisikan suatu atribut terletak dimana diagram kartesius. Berikut diagram Kartesius seperti pada Gambar 1.

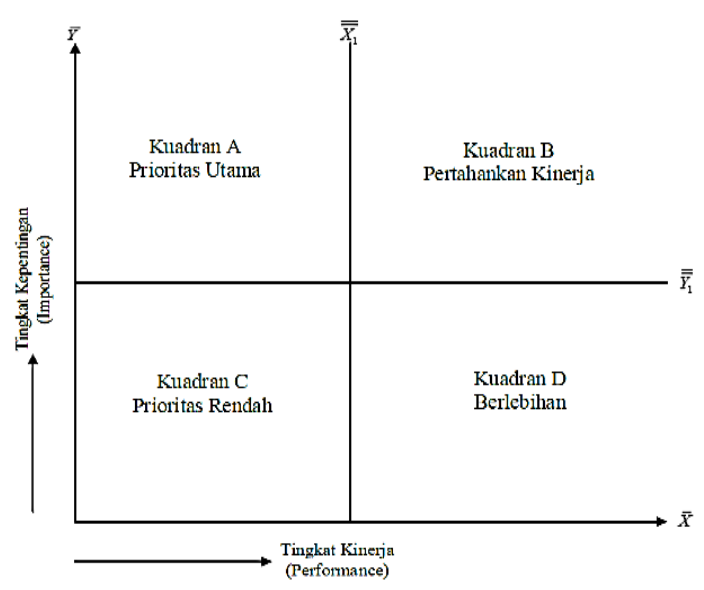

Gambar 1. Diagram Kartesius IPA

Sumber: Martilla dan James, 1977

3. Strategi Pemasaran

Bauran pemasaran merupakan kebijakan yang digunakan pada perusahaan untuk mampu memasarkan produknya dan mencapai keuntungan. Menurut Kotler dan Keller (2012), bauran pemasaran 7P yaitu Product, Price, Place, Promotion, People, Process, dan Physical evidence.

\section{HASIL DAN PEMBAHASAN}

\section{GAMBARAN UMUM TEMPAT PENELITIAN}

UMKM Salak Cristal merupakan agroindustri yang bergerak pada pengolahan salak menjadi aneka olahan produk salak. UMKM Salak Cristal beralamatkan di Jalan Salak KM 5,5 Kembang Arum, Turi, Sleman yang didirikan oleh Ibu Sri Sujarwati. Harga salak yang jatuh saat panen raya membuat Ibu Sri prihatin dan berinisiatif untuk membangun usaha pengolahan salak. Ibu Sri memulai usahanya pada tahun 2008 dengan memberi nama Salak Cristal. Pemilihan nama Cristal ini merupakan singkatan dari Cita Rasa Istimewa Tahan Lama. Harapannya dengan nama tersebut produk Cristal dapat memberikan cita rasa yang istimewa kepada konsumen sehingga konsumen selalu berkeinginan untuk membeli kembali produk Cristal.

Bahan baku didapatkan dari petani atau tengkulak di Kabupaten Sleman dengan ketentuan salak jenis pondoh dengan tingkat kematangan 75 
persen. Lokasi UMKM Salak Cristal berdekatan dengan daerah desa wisata dan tempat wisata lainnya, sehingga menjadikan wisatawan sebagai target pasarnya. Pola pemasaran yang dilakukan bermacam-macam, mulai dengan bekerjasama dengan beberapa reseller, desa wisata, rumah makan, travel, bandara, dinas pariwisata, hingga kabupaten dapat meningkatkan pendapatan penjualan. Selain itu, Salak Cristal juga melakukan penjualan secara offline melalui beberapa marketplace seperti shopee, bukalapak, tokopedia, dan gofood.

UMKM Salak Cristal mempunyai 10 orang pekerja yang terdiri dari 4 laki-laki dan 6 perempuan, di mana 4 diantaranya merupakan keluarga dan 6 lainnya berasal dari warga sekitar. Karyawan bekerja pada Senin s/d Sabtu pukul 08.00-16.00 WIB dan memiliki sistem pengupahan mingguan. UMKM Salak Cristal sewaktuwaktu dapat merekrut karyawan, tergantung pada jumlah bahan baku dan jumlah pesanan. Apabila sedang panen raya dan pesanan yang melimpah maka karyawan yang direkrut lebih banyak, guna untuk mempercepat proses produksi.

\section{KARAKTERISTIK RESPONDEN}

Domisili konsumen UMKM Salak Cristal sebagian besar berasal dari Yogyakarta. Konsumen yang berasal dari Yogyakarta ini membeli produk keripik salak untuk dibawakan sebagai buah tangan kepada keluarga atau kerabat. Konsumen yang berasal dari luar Jawa Tengah biasanya wisatawan yang membeli produk keripik salak untuk oleh-oleh. Karakteristik konsumen berdasarkan daerah domisili dapat dilihat pada Tabel 2.

Tabel 2. Karakteristik Responden Berdasarkan Daerah Domisili

\begin{tabular}{lcc}
\hline \multicolumn{1}{c}{ Jenis Kelamin } & Jumlah & Persentase (\%) \\
\hline Yogyakarta & 43 & 43 \\
Jawa Tengah & 18 & 18 \\
Luar Jawa Tengah & 39 & 39 \\
\hline Jumlah & $\mathbf{1 0 0}$ & $\mathbf{1 0 0}$ \\
\hline
\end{tabular}

Jenis kelamin merupakan salah satu faktor yang dapat mempengaruhi individu dalam menyikapi suatu produk/jasa pelayanan (Kotler dan Keller, 2012). Konsumen keripik salak UMKM Salak Cristal sebagian besar berjenis kelamin perempuan. Hal ini disebabkan oleh kecenderungan perempuan mengambil keputusan pembelian dalam kebutuhan pangan dan bertugas melakukan kegiatan belanja dan perempuan cenderung lebih memperhatikan kebutuhan anggota keluarga (Paramita, 2010). Karakteristik konsumen berdasarkan jenis kelamin dapat dilihat pada Tabel 3 .

Tabel 3. Karakteristik Responden Berdasarkan Jenis Kelamin

\begin{tabular}{lcc}
\hline Jenis Kelamin & Jumlah & Persentase (\%) \\
\hline Perempuan & 62 & 62 \\
Laki-laki & 38 & 38 \\
\hline Jumlah & $\mathbf{1 0 0}$ & $\mathbf{1 0 0}$ \\
\hline
\end{tabular}

Curatman (2010), menyatakan bahwa perbedaan usia akan mengakibatkan perbedaan selera terhadap karakteristik produk yang ditawarkan oleh penjual kepada mereka. Menurut Departemen Kesehatan RI (2009), kategori usia terbagi menjadi 9 kategori, yaitu masa balita, masa kanak-kanak, masa remaja awal, masa remaja akhir, masa dewasa awal, masa dewasa akhir, masa lansia awal, masa lansia akhir, dan manula. Pada penelitian ini, menggunakan kategori usia masa remaja awal sesuai karakteristik responden hingga yang melebihi masa dewasa akhir. Konsumen keripik salak UMKM Salak Cristal sebagian besar berada pada rentang usia 36-45 tahun. Kelompok umur tersebut merupakan kelompok usia masa dewasa akhir, sehingga cenderung berpikir rasional dalam mengambil keputusan pembelian. Menurut Setiabudi et al. (2013), kelompok usia dewasa lanjut memiliki tingkat kesadaran yang tinggi dan telah memahami kandungan gizi pada suatu produk yang baik bagi kesehatan diri sendiri dan anggota keluarganya. Karakteristik konsumen berdasarkan usia dapat dilihat pada Tabel 4.

Tabel 4. Karakteristik Responden Berdasarkan Usia

\begin{tabular}{ccc}
\hline Usia & Jumlah & Persentase (\%) \\
\hline $18-25$ & 7 & 7 \\
$26-35$ & 30 & 30 \\
$36-45$ & 44 & 44 \\
$46-55$ & 17 & 17 \\
$>56$ & 2 & 2 \\
\hline Jumlah & $\mathbf{1 0 0}$ & $\mathbf{1 0 0}$ \\
\hline
\end{tabular}


Sebagian besar responden yaitu lulusan sarjana. Hal ini menunjukkan bahwa konsumen dengan pendidikan tinggi paling tinggi karena mereka akan lebih mengetahui kelebihan dari produk keripik salak daripada konsumen dengan pendidikan rendah. Keadaan ini sejalan dengan pendapat Sumarwan (2012), bahwa konsumen yang memiliki tingkat pendidikan lebih baik akan sangat responsif terhadap informasi. Karakteristik konsumen berdasarkan tingkat pendidikan dapat dilihat pada Tabel 5 .

Tabel 5. Karakteristik Responden Berdasarkan Tingkat Pendidikan

\begin{tabular}{lcc}
\hline $\begin{array}{c}\text { Pendidikan } \\
\text { terakhir }\end{array}$ & Jumlah & Persentase (\%) \\
\hline SMA/SLTA & 29 & 29 \\
Diploma & 6 & 6 \\
Sarjana & 54 & 54 \\
Pasca Sarjana & 11 & 11 \\
\hline Jumlah & $\mathbf{1 0 0}$ & $\mathbf{1 0 0}$ \\
\hline
\end{tabular}

Jenis pekerjaan responden juga merupakan salah satu faktor yang mempengaruhi keputusan pembelian. Responden keripik salak di UMKM Salak Cristal sebagian besar bekerja sebagai pegawai swasta. Hal ini menunjukkan bahwa sebagian besar konsumen memiliki pekerjaan yang menunjang penghasilan dan berpengaruh terhadap daya beli. Menurut Sumarwan (2012), pendapatan tersebut kemudian akan mempengaruhi daya beli konsumen terhadap produk. Karakteristik konsumen berdasarkan jenis pekerjaan dapat dilihat pada Tabel 6.

Tabel 6. Karakteristik Responden Berdasarkan Jenis Pekerjaan

\begin{tabular}{lcc}
\hline \multicolumn{1}{c}{ Pekerjaan } & Jumlah & Persentase (\%) \\
\hline PNS & 11 & 11 \\
Pegawai Swasta & 44 & 44 \\
Wirausaha & 25 & 25 \\
Lainnya & 20 & 20 \\
\hline Jumlah & $\mathbf{1 0 0}$ & $\mathbf{1 0 0}$ \\
\hline
\end{tabular}

Tingkat pendapatan yang semakin tinggi maka semakin tinggi pula tingkat konsumsinya (Curatman, 2010). Pendapatan rata-rata responden sebagian besar berada pada interval $\mathrm{Rp}$ 2.004.000 - Rp 4.003.999. Konsumen UMKM Salak Cristal memiliki pendapatan rata-rata yang cukup tinggi, hal ini dikarenakan di DIY memiliki UMK sebesar Rp 2.004.000 (DIY No. 257/KEP/2019).
Curatman (2010), menyatakan bahwa pendapatan rumah tangga amat besar pengaruhnya terhadap tingkat konsumsi. Karakteristik konsumen berdasarkan tingkat pendidikan dapat dilihat pada Tabel 7.

Tabel 7. Karakteristik Responden Berdasarkan Tingkat Pendapatan

\begin{tabular}{lcc}
\hline Pendapatan (Rp/bulan) & Jumlah & $\begin{array}{c}\text { Persentase } \\
\text { (\%) }\end{array}$ \\
\hline < Rp 2.004.000 & 18 & 18 \\
Rp 2.004.000 - Rp 4.003.999 & 39 & 39 \\
Rp 4.004.000 - Rp 6.003.999 & 33 & 33 \\
Rp 6.004.000 - Rp 8.003.999 & 10 & 10 \\
$\geq$ Rp 8.004.000 & 0 & 0 \\
\hline Jumlah & $\mathbf{1 0 0}$ & $\mathbf{1 0 0}$ \\
\hline
\end{tabular}

\section{PERILAKU KONSUMEN}

Konsumen sebagian besar membeli produk keripik salak untuk oleh-oleh. Hal tersebut sesuai dengan produk yang dijual UMKM Salak Cristal yaitu produk oleh-oleh aneka olahan salak pondoh khas Sleman Yogyakarta. Menurut Sulistyowati (2013), motivasi merupakan suatu dorongan yang timbul dari diri seseorang untuk mencapai tujuan yang telah ditentukan untuk mendapatkan kepuasan. Hasil penelitian perilaku konsumen berdasarkan motivasi pembelian dapat dilihat pada Tabel 8.

\section{Tabel 8. Motivasi Pembelian Responden}

\begin{tabular}{lcc}
\hline Motivasi Pembelian & Jumlah & $\begin{array}{c}\text { Persentase } \\
\text { (\%) }\end{array}$ \\
\hline Dikonsumsi sendiri & 7 & 7 \\
Untuk oleh-oleh & 73 & 73 \\
Sekedar ingin mencoba & 7 & 7 \\
Manfaat dari buah salak & 6 & 6 \\
Lainnya & 7 & 7 \\
\hline Jumlah & $\mathbf{1 0 0}$ & $\mathbf{1 0 0}$ \\
\hline
\end{tabular}

Konsumen sebagian besar yang menjadi sumber informasi konsumen untuk mengetahui produk UMKM Salak Cristal berasal dari teman atau kerabat dan keluarga. Informasi yang diperoleh dari teman dan keluarga bersifat word of mouth (mulut ke mulut). Menurut Yunita (2012), Word of mouth dipandang sebagai sumber yang lebih dapat dipercaya dan dapat diandalkan dibanding dengan informasi nonpersonal melalui iklan. Hasil penelitian perilaku konsumen berdasarkan sumber informasi produk dapat dilihat pada Tabel 9. 
Tabel 9. Sumber Informasi Produk

\begin{tabular}{lcc}
\hline $\begin{array}{c}\text { Sumber Informasi } \\
\text { Produk }\end{array}$ & Jumlah & $\begin{array}{c}\text { Persentase } \\
\text { (\%) }\end{array}$ \\
\hline Teman/Kerabat & 48 & 48 \\
Keluarga & 22 & 20 \\
Internet/Sosial Media & 20 & 19 \\
Pameran UMKM & 1 & 1 \\
Lainnya & 9 & 12 \\
\hline Jumlah & $\mathbf{1 0 0}$ & $\mathbf{1 0 0}$ \\
\hline
\end{tabular}

Informasi yang dianggap penting oleh konsumen sebagian besar yaitu cita rasa. Rasa merupakan stimulus primer atau bentuk komunikasi yang melalui produk dan unsur-unsurnya. Sesuai dengan penelitian Budiwati (2012), menunjukkan bahwa rasa dapat mempengaruhi persepsi konsumen dalam pembelian keripik buah. Hasil penelitian perilaku konsumen berdasarkan informasi penting dapat dilihat pada Tabel 10.

Tabel 10. Informasi Penting

\begin{tabular}{lcc}
\hline Informasi Penting & Jumlah & Persentase (\%) \\
\hline Cita rasa & 63 & 63 \\
Harga produk & 17 & 17 \\
Lokasi toko & 12 & 12 \\
Kemasan produk & 6 & 6 \\
Lainnya & 2 & 2 \\
\hline Jumlah & $\mathbf{1 0 0}$ & $\mathbf{1 0 0}$ \\
\hline
\end{tabular}

Sebagian besar cara konsumen memutuskan pembelian produk dengan keputusan pembelian terencana. Hal ini disebabkan karena alasan utama pembelian yaitu untuk oleh-oleh, dimana konsumen telah merencanakan kapan akan melakukan proses pembelian produk. Menurut Iskandar et al. (2018), konsumen telah memiliki informasi yang cukup banyak tentang produk yang akan dibeli atau sudah terbiasa membeli produk tersebut, sedangkan tidak terencana karena keinginan responden untuk membeli produk seringkali baru dirasakan atau disadari ketika berada pada lokasi tersebut. Hasil penelitian perilaku konsumen berdasarkan keputusan pembelian dapat dilihat pada Tabel 11 .

Tabel 11. Keputusan Pembelian

\begin{tabular}{lcc}
\hline $\begin{array}{l}\text { Keputusan } \\
\text { Pembelian }\end{array}$ & Jumlah & Persentase (\%) \\
\hline Terencana & 73 & 73 \\
Tidak Terencana & 27 & 27 \\
\hline Jumlah & $\mathbf{1 0 0}$ & $\mathbf{1 0 0}$ \\
\hline
\end{tabular}

Sebagian besar konsumen melakukan pembelian pada waktu yang tidak tentu. Tidak tentu yaitu terkait dengan waktu pembelian konsumen, konsumen dapat melakukan pembeliaan pada saat libur ataupun saat hari kerja, sesuai dengan kebutuhan akan membeli produk dan waktu saat berwisata ke desa Turi. Waktu yang diperlukan dalam proses pengambilan keputusan ini tidak sama, tergantung dari hal-hal yang perlu dipertimbangkan dalam proses pembelian atau pengambilan keputusan tersebut. Hasil penelitian perilaku konsumen berdasarkan waktu pembelian dapat dilihat pada Tabel 12 .

Tabel 12. Waktu Pembelian

\begin{tabular}{lcc}
\hline $\begin{array}{c}\text { Waktu } \\
\text { Pembelian }\end{array}$ & Jumlah & $\begin{array}{c}\text { Persentase } \\
\text { (\%) }\end{array}$ \\
\hline Hari kerja & 0 & 0 \\
Setiap hari & 0 & 0 \\
Hari libur & 32 & 23 \\
Tidak tentu & 68 & 77 \\
Lainnya & 0 & 0 \\
\hline Jumlah & $\mathbf{1 0 0}$ & $\mathbf{1 0 0}$ \\
\hline
\end{tabular}

Jumlah pembelian produk/kemasan paling banyak yaitu dengan jumlah 3 - 6 kemasan pada ukuran kemasan 80 gr. Menurut konsumen, kemasan 80 gr cukup dalam ukuran kemasan yang berukuran sedang dan harga tidak terlalu mahal namun isinya cukup banyak. Hal ini menunjukkan bahwa jumlah pembelian produk (kemasan) terhadap keripik salak sangat beragam yang disesuaikan dengan kebutuhan. Hasil penelitian perilaku konsumen berdasarkan jumlah produk (kemasan) dapat dilihat pada Tabel 13.

Tabel 13. Jumlah Produk (Kemasan)

\begin{tabular}{|c|c|c|c|}
\hline $\begin{array}{c}\text { Ukuran } \\
\text { Kemasan }\end{array}$ & $\begin{array}{c}\text { Jumlah } \\
\text { Pembelian }\end{array}$ & $\begin{array}{c}\text { Jumlah } \\
\text { Pembelian } \\
\text { (Kemasan) }\end{array}$ & $\begin{array}{c}\text { Persen- } \\
\text { tase } \\
(\%)\end{array}$ \\
\hline \multirow{4}{*}{$50 \mathrm{gr}$} & $<3$ & 34 & \multirow{4}{*}{18} \\
\hline & $3-6$ & 16 & \\
\hline & $7-9$ & 0 & \\
\hline & $>9$ & 0 & \\
\hline \multirow{4}{*}{$80 \mathrm{gr}$} & $<3$ & 46 & \multirow{4}{*}{66} \\
\hline & $3-6$ & 123 & \\
\hline & $7-9$ & 0 & \\
\hline & $>9$ & 10 & \\
\hline \multirow{4}{*}{$250 \mathrm{gr}$} & $<3$ & 32 & \multirow{4}{*}{16} \\
\hline & $3-6$ & 12 & \\
\hline & $7-9$ & 0 & \\
\hline & $>9$ & 0 & \\
\hline Jumlah & & 273 & 100 \\
\hline
\end{tabular}


TINGKAT KEPUASAN KONSUMEN

Customer Satisfaction Index (CSI)

Berdasarkan hasil perhitungan Customer Satisfaction Index (CSI) dapat diketahui bahwa nilai indeks kepuasan konsumen keripik salak UMKM Salak Cristal secara keseluruhan sebesar
76\%. Nilai tersebut berada pada rentang $61 \%-$ $90 \%$ yang berarti konsumen keripik salak UMKM Salak Cristal berada pada kriteria puas.

Namun, terdapat $24 \%$ kepuasan konsumen yang masih belum dapat terpenuhi. Peningkatan kinerja dari atribut perlu dilakukan untuk me-

Tabel 14. Hasil Perhitungan Customer Satisfaction Index (CSI)

\begin{tabular}{|c|c|c|c|c|c|}
\hline No. & Atribut & $\begin{array}{c}\text { Mean } \\
\text { Importance } \\
\text { Score (MIS) } \\
\end{array}$ & $\begin{array}{c}\text { Mean } \\
\text { Satisfaction } \\
\text { Score (MSS) } \\
\end{array}$ & $\begin{array}{c}\text { Weight } \\
\text { Factors } \\
\text { (WF) }\end{array}$ & $\begin{array}{c}\text { Weight } \\
\text { Score } \\
\text { (WS) }\end{array}$ \\
\hline \multicolumn{6}{|c|}{ Product (Produk) } \\
\hline 1 & Cita rasa yang khas & 4,69 & 4,35 & $2,9 \%$ & 0,127 \\
\hline 2 & Variasi rasa yang beraneka ragam & 4,67 & 2,3 & $2,9 \%$ & 0,067 \\
\hline 3 & Tidak memiliki kualitas dan rasa yang khas & 4,67 & 4,35 & $2,9 \%$ & 0,127 \\
\hline 4 & Desain stiker merek pada kemasan & 4,53 & 3,93 & $2,8 \%$ & 0,111 \\
\hline 5 & Warna stiker merk \& kemasan matching & 4,07 & 4,45 & $2,5 \%$ & 0,113 \\
\hline 6 & Ukuran variasi kemasan produk bervariasi & 4,6 & 4,11 & $2,9 \%$ & 0,118 \\
\hline 7 & Bahan kemasan menjaga kualitas produk & 4,71 & 3,93 & $2,9 \%$ & 0,115 \\
\hline 8 & Desain stiker pada kemasan tidak menarik & 4,56 & 3,95 & $2,8 \%$ & 0,112 \\
\hline 9 & Informasi tentang produk tertera pada kemasan & 4,75 & 4,49 & $3,0 \%$ & 0,133 \\
\hline 10 & Informasi produk tidak tertera pada kemasan & 4,66 & 4,32 & $2,9 \%$ & 0,125 \\
\hline \multicolumn{6}{|c|}{ Price (Harga) } \\
\hline 11 & $\begin{array}{l}\text { Harga produk bervariasi sesuai dengan ukuran } \\
\text { produk }\end{array}$ & 4,64 & 4,21 & $2,9 \%$ & 0,122 \\
\hline 12 & Harga produk sesuai dengan kualitas produknya & 4,6 & 4,08 & $2,9 \%$ & 0,117 \\
\hline 13 & Harga produk tidak sesuai dengan kualitas & 4,63 & 4,17 & $2,9 \%$ & 0,120 \\
\hline \multicolumn{6}{|c|}{ Promotion (Promosi) } \\
\hline 14 & Terdapat penjualan melalui online & 4,6 & 3,11 & $2,9 \%$ & 0,089 \\
\hline 15 & Terdapat promosi melalui media sosial & 4,6 & 2,25 & $2,9 \%$ & 0,064 \\
\hline 16 & Terdapat promosi melalui pameran produk & 4,53 & 4,51 & $2,8 \%$ & 0,127 \\
\hline 17 & Tidak terdapat promosi penjualan & 4,6 & 4,51 & $2,9 \%$ & 0,129 \\
\hline \multicolumn{6}{|c|}{ Place (Tempat) } \\
\hline 18 & Kenyamanan, kebersihan, dan kerapihan toko & 4,75 & 4,36 & $3,0 \%$ & 0,129 \\
\hline 19 & Area parkir pada toko tersedia luas & 3,83 & 2,54 & $2,4 \%$ & 0,061 \\
\hline 20 & Lokasi toko mudah dijangkau atau diakses & 4,57 & 3,08 & $2,8 \%$ & 0,088 \\
\hline 21 & Lokasi toko tidak mudah dijangkau atau diakses & 4,58 & 3,08 & $2,9 \%$ & 0,088 \\
\hline \multicolumn{6}{|c|}{ People (Orang) } \\
\hline 22 & Karyawan menggunakan baju seragam & 4,57 & 2,2 & $2,8 \%$ & 0,063 \\
\hline 23 & Karyawan berpenampilan rapi dalam berpakaian & 4,6 & 3,66 & $2,9 \%$ & 0,105 \\
\hline 24 & Karyawan ramah dan sopan & 4,6 & 4,06 & $2,9 \%$ & 0,116 \\
\hline 25 & Karyawan aktif merespon konsumen & 4,54 & 4,21 & $2,8 \%$ & 0,119 \\
\hline 26 & Karyawan tidak aktif merespon konsumen & 4,7 & 4,41 & $2,9 \%$ & 0,129 \\
\hline \multicolumn{6}{|c|}{ Process (Proses) } \\
\hline 27 & Karyawan memberikan tester kepada konsumen & 4,61 & 4,17 & $2,9 \%$ & 0,120 \\
\hline 28 & Karyawan sigap dalam melayani konsumen & 4,62 & 3,89 & $2,9 \%$ & 0,112 \\
\hline 29 & Kemudahan proses pembayaran & 4,6 & 2,3 & $2,9 \%$ & 0,066 \\
\hline 30 & Karyawan tidak aktif dan sigap dalam melayani & 4,71 & 4,08 & $2,9 \%$ & 0,120 \\
\hline \multicolumn{6}{|c|}{ Physical Evidence (Pendukung Fisik) } \\
\hline 31 & Display produk tertata dengan baik & 4,7 & 4,18 & $2,9 \%$ & 0,122 \\
\hline 32 & Display produk memudahkan konsumen dalam & & & & \\
\hline & mencari dan melihat produk & 4,64 & 4,39 & $2,9 \%$ & 0,127 \\
\hline 33 & $\begin{array}{l}\text { Display produk sesuai dengan jumlah dan macam } \\
\text { produk yang di pajang }\end{array}$ & 4,56 & 3,42 & $2,8 \%$ & 0,097 \\
\hline 34 & $\begin{array}{l}\text { Label harga produk ter-display sesuai dengan tiap } \\
\text { produk }\end{array}$ & 4,57 & 3,63 & $2,8 \%$ & 0,103 \\
\hline 35 & Display produk tidak tertata dengan baik & 4,61 & 4,22 & $2,9 \%$ & 0,121 \\
\hline & Total & 158,20 & 129,50 & $100,0 \%$ & 3,804 \\
\hline & Rata-rata & 4,52 & 3,70 & 0,028 & 0,108 \\
\hline & CSI & & $76,01 \%$ & & \\
\hline
\end{tabular}


ningkatkan persentase kepuasan konsumen. UMKM Salak Cristal harus memprioritaskan atribut mana saja yang harus dikembangkan dan diperbaiki terlebih dahulu mengingat keterbatasan sumber daya yang dimiliki. Prioritas kinerja atribut produk yang harus ditingkatkan dilakukan berdasarkan hasil matriks dari IPA. Hasil perhitungan CSI dapat dilihat pada Tabel 14.

\section{Importance Performance Analysis (IPA)}

Berdasarkan hasil perhitungan CSI, maka akan dihasilkan suatu perhitungan tingkat kesesuaian. Tingkat kesesuaian inilah yang akan menentukan urutan prioritas perbaikan kinerja atribut yang akan mempengaruhi kepuasan konsumen. Tingkat kesesuaian merupakan hasil perbandingan antara skor tingkat kinerja dengan skor kepentingan yang akan menentukan urutan prioritas peningkatan kinerja setiap atribut yang mempengaruhi kepuasan konsumen dalam satu kuadran (Supranto, 2006). Hasil perhitungan tingkat kesesuaian dapat dilihat pada Tabel 15.

Berdasarkan Tabel 15, terdapat 10 atribut yang memiliki tingkat kesesuaian dibawah ratarata. Hal ini menunjukkan bahwa atribut tersebut memiliki nilai kepentingan yang tinggi namun memiliki nilai kinerja yang rendah, sehingga atribut tersebut perlu perbaikan untuk mencapai

Tabel 15. Hasil Perhitungan Tingkat Kesesuaian

\begin{tabular}{|c|c|c|c|c|}
\hline No. & Atribut & $\begin{array}{c}\text { Tingkat } \\
\text { Kinerja } \\
\text { (Xi) }\end{array}$ & $\begin{array}{c}\text { Tingkat } \\
\text { Kepentingan } \\
\text { (Yi) }\end{array}$ & $\begin{array}{c}\text { Tingkat } \\
\text { Kesesuaian } \\
\text { Tk (\%) } \\
\end{array}$ \\
\hline 1 & Cita rasa yang khas & 435 & 469 & 93 \\
\hline 2 & Variasi rasa yang beraneka ragam & 230 & 467 & 49 \\
\hline 3 & Tidak memiliki kualitas dan rasa yang khas & 435 & 467 & 93 \\
\hline 4 & Desain stiker merek pada kemasan & 393 & 453 & 87 \\
\hline 5 & Warna stiker merk \& kemasan matching & 445 & 407 & 109 \\
\hline 6 & Ukuran variasi kemasan produk bervariasi & 411 & 460 & 89 \\
\hline 7 & Bahan kemasan menjaga kualitas produk & 393 & 471 & 83 \\
\hline 8 & Desain stiker pada kemasan tidak menarik & 395 & 456 & 87 \\
\hline 9 & Informasi tentang produk tertera pada kemasan & 449 & 475 & 95 \\
\hline 10 & Informasi produk tidak tertera pada kemasan & 432 & 466 & 93 \\
\hline 11 & Harga produk bervariasi sesuai dengan ukuran & 421 & 464 & 91 \\
\hline 12 & Harga produk sesuai dengan kualitas produknya & 408 & 460 & 89 \\
\hline 13 & Harga produk tidak sesuai dengan kualitas & 417 & 463 & 90 \\
\hline 14 & Terdapat penjualan melalui online & 311 & 460 & 68 \\
\hline 15 & Terdapat promosi melalui media sosial & 225 & 460 & 49 \\
\hline 16 & Terdapat promosi melalui pameran produk & 451 & 453 & 100 \\
\hline 17 & Tidak terdapat promosi penjualan & 451 & 460 & 98 \\
\hline 18 & Kenyamanan, kebersihan, dan kerapihan toko & 436 & 475 & 92 \\
\hline 19 & Area parkir pada toko tersedia luas & 254 & 383 & 66 \\
\hline 20 & Lokasi toko mudah dijangkau atau diakses & 308 & 457 & 67 \\
\hline 21 & Lokasi toko tidak mudah dijangkau atau diakses & 308 & 458 & 67 \\
\hline 22 & Karyawan menggunakan baju seragam & 220 & 457 & 48 \\
\hline 23 & Karyawan berpenampilan rapi dalam berpakaian & 366 & 460 & 80 \\
\hline 24 & Karyawan ramah dan sopan & 406 & 460 & 88 \\
\hline 25 & Karyawan aktif merespon konsumen & 421 & 454 & 93 \\
\hline 26 & Karyawan tidak aktif merespon konsumen & 441 & 470 & 94 \\
\hline 27 & Karyawan memberikan tester kepada konsumen & 417 & 461 & 90 \\
\hline 28 & Karyawan sigap dalam melayani konsumen & 389 & 462 & 84 \\
\hline 29 & Kemudahan proses pembayaran & 230 & 460 & 50 \\
\hline 30 & Karyawan tidak aktif dan sigap dalam melayani & 408 & 471 & 87 \\
\hline 31 & Display produk tertata dengan baik & 418 & 470 & 89 \\
\hline \multirow[t]{2}{*}{32} & Display produk memudahkan konsumen dalam mencari dan & & & \\
\hline & melihat produk & 439 & 464 & 95 \\
\hline \multirow[t]{2}{*}{33} & Display produk sesuai dengan jumlah dan macam produk & & & \\
\hline & yang dipajang & 342 & 456 & 75 \\
\hline 34 & Label harga produk ter-display sesuai dengan tiap produk & 363 & 457 & 79 \\
\hline \multirow[t]{3}{*}{35} & Display produk tidak tertata dengan baik & 422 & 461 & 92 \\
\hline & Total & 13290 & 16047 & 2898 \\
\hline & Rata-rata & 379,71 & 458,49 & 83 \\
\hline
\end{tabular}


kepuasan konsumen. Atribut tersebut yaitu, variasi rasa, penjualan melalui online, promosi online, lokasi toko, seragam karyawan, penampilan karyawan, kemudahan proses pembayaran, display produk sesuai jumlah produk dan label harga produk. Adapun atribut yang memiliki nilai kepentingan yang lebih tinggi daripada nilai kinerjanya yaitu atribut warna kemasan. Selain itu, atribut yang memiliki nilai kinerjanya lebih tinggi dari nilai kepentingan adalah atribut area parkir toko. Atribut lainnya memiliki tingkat kepentingan di atas rata-rata namun masih di bawah 100 persen. Tahap selanjutnya yaitu menentukan prioritas dengan menggunakan diagram kartesius.

Diagram kartesius IPA merupakan salah satu alat bantu untuk menentukan prioritas perbaikan atribut dengan menggambarkan tingkat kinerja masing-masing atribut. Diagram kartesius akan menunjukkan skor rata-rata kepentingan dan skor rata-rata tingkat kinerja dengan nilai rata-rata masing-masing 4.52 dan 3.70. Skor rata- rata kinerja menunjukkan posisi dari suatu atribut pada sumbu X, dan skor rata-rata kepentingan atau harapan berada pada posisi sumbu Y. Hasil tersebut akan terlihat atribut mana saja yang perlu diperbaiki dan mana saja yang dipertahankan. Diagram kartesius dapat dilihat pada Gambar 2.

Berdasarkan Gambar 2, kuadran I merupakan kuadran dimana konsumen memiliki tingkat kepentingan yang tinggi namun memiliki tingkat kinerja yang rendah. Sehingga, atribut yang berada di kuadran I harus menjadi prioritas utama bagi UMKM Salak Cristal dalam perbaikan kinerja, agar dapat memenuhi serta meningkatkan kepuasan konsumen. Atribut-atribut tersebut yaitu variasi rasa, penjualan online, promosi online, lokasi toko, seragam karyawan, kerapihan karyawan, proses pembayaran, display sesuai jumlah produk, dan label harga produk.

Kuadran II merupakan kuadran dimana konsumen memiliki tingkat harapan atau kepentingan yang tinggi dan telah dilaksanakan dengan baik serta membuat konsumen merasa

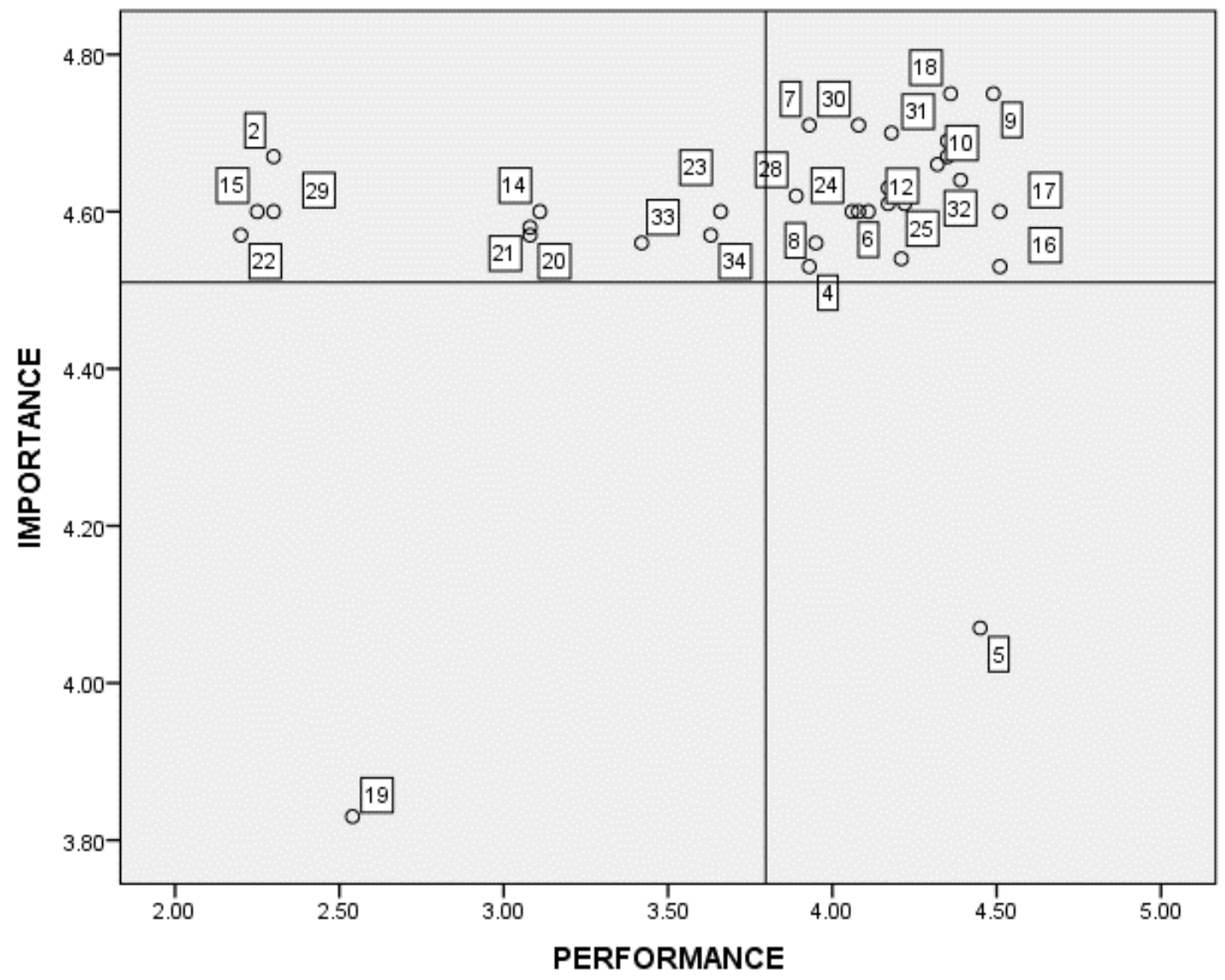

Gambar 2. Pemetaan Atribut pada Diagram Kartesius IPA 
puas. Hal ini menuntut UMKM Salak Cristal untuk dapat mempertahankan dan meningkatkan kinerjanya. Atribut-atribut tersebut yaitu cita rasa, desain stiker, variasi ukuran kemasan, bahan kemasan, informasi produk, harga bervariasi, harga sesuai kualitas, promosi pameran, kenyamanan toko, keramahan dan kesopanan karyawan, keaktifan karyawan, adanya tester, kesigapan karyawan, display produk tertata, dan display memudahkan mencari produk.

Kuadran III merupakan kuadran dimana konsumen memiliki tingkat harapan rendah dan pada kenyataannya kinerja dari perusahaan tidak terlalu istimewa. Perbaikan atau peningkatan kinerja atribut dapat dipertimbangkan kembali karena pengaruhnya kecil terhadap konsumen. Atribut tersebut yaitu parkiran toko.

Kuadran IV merupakan kuadran dimana konsumen memiliki tingkat harapan yang rendah, akan tetapi pada pelaksanaannya telah dijalankan dengan sangat baik oleh UMKM Salak Cristal sehingga konsumen merasa berlebihan. Kinerja atribut-atribut yang masuk dalam kuadran ini dapat dikurangi agar UMKM Salak Cristal dapat menghemat biaya-biaya atribut tersebut. Atribut tersebut yaitu warna stiker merek.

\section{Strategi Pemasaran}

1. Produk (product)

UMKM Salak Cristal perlu mengembangkan produknya, dengan menciptakan inovasi dan menciptakan varian rasa untuk keripik salak. Variasi rasa tersebut dapat berupa rasa manis, pedas, atau gurih. Adanya variasi rasa tersebut akan memberikan banyak pilihan kepada konsumen untuk memilih produk yang paling disukai.

\section{Harga (price)}

Harga produk yang ditetapkan oleh UMKM Salak Cristal telah melalui perhitungan dan sesuai dengan target market yang dibidik. UMKM Salak Cristal perlu mengetahui harga produk pada pesaing lainnya sebagai pembanding, agar konsumen dapat merasakan dan menilai bahwa harga dan kualitas produk keripik salak yang diberikan telah sesuai.

\section{Tempat (place)}

Toko Salak Cristal berdekatan dengan beberapa desa wisata atau lokawisata yang berada di Turi Sleman, namun lokasi pemasaran yang cukup jauh dari perkotaan dan tidak adanya petunjuk jalan ke lokasi toko menjadi pertimbangan konsumen dalam pembelian. Oleh karena itu, perlu ditingkatkan dengan beberapa cara yaitu membuat petunjuk jalan ke lokasi toko dan memilih lokasi toko atau cabang yang strategis dengan pusat perbelanjaan oleh-oleh.

\section{Promosi (promotion)}

Konsumen masih banyak yang belum mengetahui sosial media UMKM Salak Cristal. Hal ini menunjukkan belum maksimalnya promosi secara online yang dilakukan UMKM Salak Cristal, sehingga perlu ditingkatkan dengan membuat tampilan dan konten yang menarik pada sosial media yang digunakan seperti menjelaskan tentang produk, informasi tentang salak, melakukan promosi, ataupun kuis untuk konsumen agar menarik perhatian konsumen, meningkatkan engagement dengan konsumen dengan cara merespon komentar atau pesan masuk, serta melakukan endorsement. Selain itu juga perlu meningkatkan intensitas dalam mengikuti pameran UMKM.

\section{Orang (people)}

Karyawan memiliki tugas atau job desk yang tumpang tindih atau double job. Tidak adanya seragam bagi karyawan juga menjadikan karyawan kurang terlihat rapi. Sehingga hal tersebut perlu ditingkatkan dengan membuat SOP (Standard Operating Procedure) kerapihan dan penggunaan seragam kerja untuk karyawan.

\section{Proses (process)}

Proses pembayaran masih dirasa kurang oleh konsumen karena sistem pembayaran yang masih manual manjadikan konsumen harus mengantri dan menunggu. UMKM Salak Cristal masih menggunakan proses pembayaran sederhana dengan memberikan nota yang 
ditulis secara manual. Oleh karena itu, UMKM Salak Cristal perlu meningkatkan kemudahan proses pembayaran untuk mencapai kepuasan konsumen dengan menyiapkan pembayaran secara e-money atau kartu debit dan menggunakan mesin kasir.

\section{Bukti fisik (physical evidence)}

Rak display terkadang tidak dipenuhi oleh produk karena produk yang telah dikemas terkadang tidak langsung di display sehingga membuat beberapa space rak display terlihat kosong dan label harga produk belum seluruhnya terpasang. Oleh karena itu, hal tersebut perlu diperbaiki dengan melakukan controlling stock pada display secara rutin agar mengetahui ketersediaan dan kerapihan stock pada display, melakukan penataan produk dengan metode FIFO (First in First Out) yang berarti meletakan produk yang lebih dulu datang pada rak bagian depan agar rak tidak terlihat kosong, dan membuat label harga pada rak display.

\section{SIMPULAN DAN SARAN}

\section{SIMPULAN}

Nilai tingkat kepuasan konsumen terhadap atribut produk keripik salak UMKM Salak Cristal yaitu berada pada kriteria puas. Strategi pemasaran yang dapat dilakukan UMKM Salak Cristal untuk meningkatkan tingkat kepuasan konsumen, yaitu variasi rasa, penjualan online, promosi online, lokasi toko, seragam karyawan, kerapihan karyawan, proses pembayaran, display sesuai rak produk yang tersedia, dan label harga produk.

\section{SARAN}

Perbaikan yang dapat dilakukan oleh UMKM Salak Cristal yaitu dengan menambah variasi rasa keripik salak. Membuat SOP (Standard Operating Procedure) kerapihan dan penggunaan seragam kerja untuk karyawan. Menyiapkan pembayaran secara $e$-money atau kartu debit dan menggunakan mesin kasir. Melakukan controlling stock pada display secara rutin agar mengetahui ketersediaan dan kerapihan stock pada display, melakukan penataan produk dengan metode FIFO
(First in First Out) yang berarti meletakan produk yang lebih dulu datang pada rak bagian depan agar rak tidak terlihat kosong, dan membuat price tag produk pada rak display. Membuat tampilan dan konten yang menarik pada sosial media yang digunakan seperti menjelaskan tentang produk, informasi tentang salak, melakukan promosi, ataupun kuis untuk konsumen agar menarik perhatian konsumen, meningkatkan engagement dengan konsumen dengan cara merespon komentar atau pesan masuk, serta melakukan endorsement. Membuat petunjuk jalan ke lokasi toko dan memilih lokasi toko atau cabang yang strategis dengan pusat perbelanjaan oleh-oleh.

\section{DAFTAR PUSTAKA}

Arikunto, S. 2006. Metode Penelitian Kualitatif. Jakarta (ID): Bumi Aksara.

Aritonang, R.L. 2005. Kepuasan Konsumen. Jakarta (ID): Gramedia.

[BPS] Badan Pusat Statistika. 2019. PDB Triwulanan Atas Dasar Harga Konstan 2010 Menurut Lapangan Usaha (Miliar Rupiah), 2016-2019. Jakarta Pusat (ID): BPS Jakarta.

DIY. 2018. Produksi Salak di Provinsi Daerah Istimewa Yogyakarta. Daerah Istimewa Yogyakarta (ID): BPS Yogyakarta.

DIY. 2014. Produksi Tanaman Buah Tahunan di DIY 2014-2018. Daerah Istimewa Yogyakarta (ID): BPS Yogyakarta.

Bimantio, M. 2018. Simulasi Peningkatan Pendapatan Industri Salak Pondoh di Kabupaten Sleman dengan Konsep Sinergi ABG (Academic-Business-Goverment). [thesis]. Yogyakarta [ID]: Jurusan Teknik Sistem, Universitas Gajah Mada.

Budiwati, H. 2012. Implementasi Marketing Mix dan Pengaruhnya terhadap Keputusan Pembelian Konsumen pada Produk Unggulan Keripik Pisang Agung Di Kabupaten Lumajang. Jurnal Ekonomi, 2(2). doi:10.30741/wiga.v2i2.68.

Curatman, Aang. 2010. Teori Ekonomi Makro. Yogyakarta (ID): Swagati Press. 
Dinas Perindustrian, Perdagangan, dan Koperasi Kabupaten Sleman. 2019. Jumlah unit usaha pengolahan salak di Kabupaten Sleman. Kabupaten Sleman, Yogyakarta (ID): Dinperindagkop.

Dinas Kesehatan, Departemen Kesehatan Republik Indonesia. 2009. Kategori Usia. Jakarta Pusat (ID): Dinas Kesehatan.

Fauzi, Alfiyan H. 2018. Analisis Kepuasan Konsumen untuk Meningkatkan Brand Image pada Brownies Singkong "BrownCo" [skripsi]. Bogor (ID): Fakultas Teknologi Pertanian, Institut Pertanian Bogor.

Iskandar, M., M, Turukay, \& E, Leaternia. 2018. Analisis Tingkat Kepuasan Konsumen Terhadap Produk Jus Pala KUD Tomasiwa Morella di Kota Ambon. Jurnal Agribisnis Kepulauan, 6(3). Universitas Pattimura. doi:10.30598/agrilan.v6i3.806.

Kotler, P. \& K. Keller. 2012. Manajemen Pemasaran. Edisi 12. Jakarta (ID): Erlangga.

Martilla, J.A., dan James, J.C. 1977. Importance Performance Analysis. Journal of Marketing.

Paramita Dewi, Dian. 2010. Analisis Tipe Perilaku Konsumen dalam Membeli di Pasar Tradisional Kabupaten Wonogiri [skripsi]. Surakarta (ID): Fakultas Pertanian, Universitas Sebelas Maret.

Pemerintah Indonesia. 2002. Keputusan Gubernur Daerah Istimewa Yogyakarta tentang Penetapan Upah Minimum Kabupaten/Kota tahun 2020. Keputusan Gubernur DIY No. 257/KEP/2019. Daerah Istimewa Yogyakarta.

Setiabudi, M.U., W.B. Parera \& R.A. FarFar. 2013. Proses Pengambilan Keputusan Konsumen dalam Pembelian Sayuran Segar Studi Kasus Hypermart Ambon City Center Kota Ambon. Jurnal Agribisnis Kepulauan, 1(4).

Sulistyowati, E. 2013. Motivasi dan Perilaku Konsumen dalam Keputusan Pembelian Produk Industri Kerajinan Kulit di Yogyakarta. Jurnal Maksipreneur, 2(2). Fakultas Ekonomi, Universitas Proklamasi 45. doi: 10.30588/jmp.v3i2.156

Sumarwan, Ujang. 2012. Riset Pemasaran dan Konsumen. Bogor (ID): PT Penerbit IPB Press.
Supranto, J. 2006. Pengukuran Tingkat Kepuasan Konsumen: Untuk Menaikkan Pangsa Pasar. Jakarta (ID): Rineka Cipta.

Umar, Husein. 2002. Riset Pemasaran \& Perilaku Konsumen. Jakarta (ID): Gramedia.

Yunita A. dan Haryanto, J. O. 2012. Pengaruh Word of Mouth, Iklan dan Atribut Produk terhadap Keputusan Pembelian dan Loyalitas Konsumen. Jurnal Manajemen Teknologi, 11 (1) 